\title{
Comparative Studies of Span Growth on Different Grains Substrate in Three Pleurotus spp. (Pleurotus florida, Pleurotus flabellatus and Pleurotus sapidus)
}

\author{
Ajay Kumar Mishra*, Gopal Singh, Abhishek Kumar, Amit Kumar Yadav and Mohit
}

Department of Plant Pathology, College of Agriculture, S.V.P. University of Agriculture and Technology, Meerut- 250110, UP, India

*Corresponding author

\section{A B S T R A C T}

\section{Keywords}

Mycelium, Spawn, Grains Substrate, florida, flabellatus, sapidus

\section{Article Info}

Accepted:

22 May 2018

Available Online:

10 June 2018

Mushroom is a popular nutrient and protein-rich food of the world. Oyster mushroom is the second most popular mushroom after button mushroom all over the world. Oyster mushrooms are the important and least expensive to grow, they are well known for conversion of crop residues to food proteins. Growing medium of the mushroom is generally known as substrate. It is the base of mushroom cultivation same as soil for crops. The present investigations were carried out on Comparative studies of span growth on different grains substrate in three Pleurotus spp. (Pleurotus florida, Pleurotus flabellatus and Pleurotus sapidus). The results of present investigations showed that the spawn improvement maximum mycelial growth of strains $P$. florida, $P$. flabellatus and $P$. sapidus on maize and sorghum grains. $P$. sapidus maximum mycelium growth was observed in Maize grain $(90 \mathrm{~mm})$ and $P$. florida shows maximum mycelium growth was observed in Maize grain $(89.25 \mathrm{~mm})$ while minimum mycelium growth was found in Wheat grain substrate (54.5) and in case of P. flabellatus maximum mycelium growth was observed in Maize grain $(86.50 \mathrm{~mm})$. Based on the results obtained, maize grain would be recommended as most suitable substrate for the cultivation of all three Pleurotus spp.

\section{Introduction}

Mushrooms are fruiting bodies of fungi. They are classified in Kingdom of Fungi, which is also called Kingdom of Mycetae. The use of mushrooms as food is an old age practice and there is cultivation record in 60 A.D. (Chang and Miles, 2004). Mushrooms are considered as a source of high quality protein and crops possessing high medicinal and economical values. Mushroom farming has two inseparable phases; spawn production and fruiting body cultivation. Spawn is the planting seed of mushroom and technically, it is an expanding mushroom mycelium colonizing a given substrate media. Currently, albeit mushrooms are cultivated in more than 100 countries (Chang S-T, 2006). Cultivated species of mushroom, Pleurotus exhibits much diversity in the adaptability to varying climates, and this flexible nature makes it a more cultivated species than any other cultivated mushroom. Out of 28 species reported from India, more than a dozen are 
under cultivation in different part of the country (Verma, 1998).

Spawn is the vegetative mycelium from a selected mushroom grown on a convenient medium like wheat, pearl millet, sorghum, etc for raising mushroom crop. It essentially involves preparation of pure culture of mushroom from tissues/ spores that is generally maintained in any agar medium, followed by culturing on sterilized grains and further multiplied on grains. The spawn thus comprises of mycelium of the mushroom and a supporting medium which provides nutrition to the fungus during its growth. From 1652 to 1894 A.D. spawn was gathered from the wild rather than made. Before the advent of grain spawn, different kinds of spawn used were natural or Virgin spawn (from the pastures \& meadows), Flake spawn (breaking of beds through which mushroom mycelium has run), Mill track spawn (bricks dried and made from mixture of horse dung, cow dung and loan soil) and manure spawn (on sterilized horse manure or compost manure).

Thus, Production of good quality spawn requires a strict laboratory procedure in which maintaining sanitation and purity of the spawn are critical importance. The quality of spawn affects both yield and quality of cultivated mushrooms (Mbogoh, 2011). Spawn production is a fermentation process in which the mushroom mycelium will be increased by growing through a solid organic matrix under controlled environmental condition. In almost all cases the organic matrix will be sterilized grain e.g. wheat, maize, sorghum etc (Jain, 2005).

Species of Pleurotus are grown on a more limited scale (Royse and Schisler, 1980). P. florida was isolated from subtropical Florida in U.S.A. and commercially exploited (Zadrazil, 1980). P. flabellatus was grown successfully in India (Bano and Srivastava,
1962) and Philippines (Quimio, 1978). Thus, the objective of this study was mainly to assess the effect of different locally available grain substrates for spawn production of Oyster mushroom (Pleurotus florida, Pleurotus flabellatus and Pleurotus sapidus).

\section{Materials and Methods}

\section{Experimental site}

The experiments were conducted during 20152016 in Mushroom Laboratory Department Plant of Pathology, S. V. P. University of Agriculture and Technology, Meerut, UP, India, which is situated on the Western side of the Delhi-Dehradun high way (NH-58) at a distance of $10.0 \mathrm{~km}$ away in the north of Meerut city. The district Meerut is situated between $29^{\circ} 01^{\prime} \mathrm{N}$ latitude and $77^{\circ} 45^{\prime} \mathrm{E}$ longitude at an altitude of 237 meters above the mean sea level.

\section{Establishment of pure culture}

Culture of Pleurotus spp. (P. florida, $P$. flabellatus and $P$. sapidus) were purified and maintained by single hyphal tip method. For this purpose, the culture was grown in sterilized Petri plates on Potato Dextrose Agar Medium (PDA) for 8-10 days. Single branched hyphae from the periphery of the growing colony were marked under low power (10x) in the compound microscope and transferred to PDA slants. These tubes were incubated at $24 \pm^{0} \mathrm{C}$ for about a week, again sub cultured on PDA and then stored in a refrigerator at $5 \pm^{0} \mathrm{C}$ for further use.

\section{Spawn Improvement}

Spawn was prepared on healthy and clean wheat grains in half litre capacity wide mouthed glass bottles. After that, the grains were soaked overnight in clean water and then washed. They were boiled in water for 15 
minutes taking care that grains should not split but remain slightly hard after boiling. The boiled grains were spread in thin layer over a wire net to remove excessive water and enable them to cool about $25 \pm 1^{0} \mathrm{C}$. The cooled grains were then mixed with 1.2 percent commercial grade gypsum $\left(\mathrm{CaSO}_{4}\right)$ and 0.3 percent calcium carbonate $\left(\mathrm{CaCO}_{3}\right)$. Gypsum prevents the sticking of wheat grains together and calcium carbonate maintains the $\mathrm{pH}$ 5.5-7.5. The grains were then filled in clean glass bottle up to $2 / 3^{\text {rd }}$ of its capacity. The bottles were plugged with non-absorbent cotton and covered with butter paper. These bottles were then sterilized at $121^{\circ} \mathrm{C}$ (15 lbs pressure) for 2 hours on two consecutive days. Sterilized bottles were taken out from the autoclave, while still hot and were shaken to avoid clumping of grains. Sterilized bottles were inoculated with few $9 \mathrm{~mm}$ disc of a vigorously grown 10 days old culture of Pleurotus spp., Inoculated bottles were incubated at $24 \pm 1{ }^{\circ} \mathrm{C}$ and shaking was done after 7 days. Entire grains were covered with fine mycelial growth after $20 \pm 1$ days. This spawn is known as mother spawn or master spawn which were used for the study of present investigation.

\section{Effect of different grains on spawn growth}

In this experiment, different types of grains were used as substrate (i.e. sorghum, oat, barley, pearl millet, maize and wheat). The Spawn was prepared as described under 3.6. The grains were filled up to $(90 \mathrm{~mm})$ in the bottle for six treatments in four replicates. Pleurotus spp. (P. florida, P. flabellatus and $P$. sapidus) were inoculated by $9 \mathrm{~mm}$ disc in individual bottle bottle under laminar air flow. The spawn bottles were incubated without shaking at $24 \pm 1^{0} \mathrm{C}$ in B.O.D incubator and observations were recorded for the spawn on $4^{\text {th }}, 8^{\text {th }} \& 12^{\text {th }}$ day till the first bottle completely covered by mycelial growth (i.e. $90 \mathrm{~mm}$ ) in anyone grains used in the spawns bottles.

\section{Experimental design}

In the experiments complete randomized design (CRD) with three replicates of each. Sorghum spawn, oat spawn, barley spawn, pearl millet spawn, maize spawn and wheat spawn, in all six types of substrates.

\section{Data analysis}

Data were analyzed using the analysis of variance (ANOVA) procedure by O. P. STAT.

\section{Results and Discussion}

\section{Effect of different grain substrate on spawn growth}

The maximum spawn growth $(34.75 \mathrm{~mm})$ was found in maize grain followed by oat grain $(21.00 \mathrm{~mm})$ on $4^{\text {th }}$ day which was significantly lower than maize while minimum mycelium growth were observed in wheat grain (17.50 $\mathrm{mm})$ followed by pearl millet $(19.50 \mathrm{~mm})$ which was significantly similar to wheat grain. In case of $P$. flabellatus on $4^{\text {th }}$ day maximum mycelial growth $(32.50 \mathrm{~mm})$ was recorded in maize grain followed by oat grain $(21.50 \mathrm{~mm})$ which was significantly lower than maize while minimum mycelium growth were recorded in wheat grain $(16.25 \mathrm{~mm})$ followed by pearl millet and sorghum $(18.50 \mathrm{~mm})$ both which was significantly similar to barley grain. In case of $P$. sapidus on $4^{\text {th }}$ day maximum mycelial growth $(36.50 \mathrm{~mm})$ was recorded in maize grain followed by sorghum grain $(29.25 \mathrm{~mm})$ which was significantly lower than maize while minimum mycelium growth were recorded in pearl millet grain $(20.00 \mathrm{~mm})$ followed by oat grain $(23.75 \mathrm{~mm})$ which was significantly higher than pearl millet grain.

On $8^{\text {th }}$ day, maximum spawn growth $(62.00$ $\mathrm{mm}$ ) was found in maize grain followed by barley grain $(45.50 \mathrm{~mm})$ which was 
significantly lower than maize while minimum mycelium growth were recorded in wheat grain $(32.00 \mathrm{~mm})$ followed by pearl millet $(32.25 \mathrm{~mm})$ which was significantly similar to wheat grain in case of $P$. florida while in case of $P$. flabellatus on $8^{\text {th }}$ day maximum mycelial growth $(60.75 \mathrm{~mm})$ was observed in maize grain followed by oat grain $(43.50 \mathrm{~mm})$ which was significantly lower than maize while minimum mycelium growth were recorded in wheat grain $(31.5 \mathrm{~mm})$ followed by pearl millet $(32.25 \mathrm{~mm})$ which was significantly similar to wheat grain. In case of $P$. sapidus on $8^{\text {th }}$ day maximum mycelial growth $(60.75$ $\mathrm{mm}$ ) was recorded in maize grain followed by barley grain $(46.25 \mathrm{~mm})$ which was significantly lower than maize while minimum mycelium growth were recorded in pearl millet grain $(40.50 \mathrm{~mm})$ followed by wheat grain $(44.75 \mathrm{~mm})$ which was significantly higher than pearl millet grain.

On $12^{\text {th }}$ day maximum spawn growth $(89.25$ $\mathrm{mm}$ ) in $P$. florida was found in maize grain followed by oat grain $(76.25 \mathrm{~mm})$ which was significantly lower than maize while minimum mycelium growth were recorded in wheat grain $(54.50 \mathrm{~mm})$ followed by pearl millet $(58.50 \mathrm{~mm})$ which was significantly higher than wheat grain.

In case of $P$. flabellatus on $12^{\text {th }}$ day, maximum mycelial growth $(86.50 \mathrm{~mm})$ was recorded in maize grain followed by oat grain $(71.50 \mathrm{~mm})$ which was significantly lower than maize while minimum mycelium growth were recorded in wheat grain $(50.75 \mathrm{~mm})$ followed by pearl millet $(59.50 \mathrm{~mm})$ which was significantly higher than wheat grain. In case of $P$. sapidus on $12^{\text {th }}$ day maximum mycelial growth $(90.00 \mathrm{~mm})$ was recorded in maize grain followed by barley grain $(89.00 \mathrm{~mm})$ which was significantly lower than maize while minimum mycelium growth were recorded in pearl millet grain $(69.00 \mathrm{~mm})$ followed by barley grain $(76.00 \mathrm{~mm})$ which was significantly higher than pearl millet grain. Regarding spawn growth rate (mm/day) in all three Pleurotus species maximum spawn growth rate was found in maize grain, in case of $P$. florida $(7.44 \mathrm{~mm} /$ day $)$ followed by oat grain $(6.35 \mathrm{~mm} /$ day $)$ and minimum growth rate was found in Wheat grain $(4.54 \mathrm{~mm} /$ day $)$ followed by pearl millet $(4.88 \mathrm{~mm} /$ day $)$.

In case of $P$. flabellatus maximum spawn growth rate was found in maize grain (7.21 $\mathrm{mm}$ /day) followed by oat grain $(5.96 \mathrm{~mm} /$ day $)$ and minimum growth rate was found in wheat grain $(4.23 \mathrm{~mm} /$ day $)$ followed by pearl millet (4.96 $\mathrm{mm} / \mathrm{day})$. In case of $P$. sapidus maximum spawn growth rate was found in maize grain $(7.50 \mathrm{~mm} /$ day $)$ followed by sorghum grain $(7.42 \mathrm{~mm} /$ day $)$ and minimum growth rate was found in pearl millet $(5.75$ $\mathrm{mm}$ /day) followed by barley grain (6.33 $\mathrm{mm} /$ day).

In the present investigation, all Pleurotus species i.e. P. florida, $P$. flabellatus and $P$. sapidus grown on different grain substrates in spawn bottles, took different time to complete mycelial growth $(90 \mathrm{~mm})$. Full mycelial growth of strains $P$. florida, $P$. flabellatus and $P$. sapidus in maize and sorghum grain was obtained on $12^{\text {th }}$ days in spawn bottles which is significantly superior to other grain spawn. Among the other grains mycelial growth of maize were followed by sorghum $(89 \mathrm{~mm})$ and oat $(82.25 \mathrm{~mm})$ from the strain $P$. sapidus at $12^{\text {th }}$ day observations while in case of $P$. florida, mycelial growth of maize were followed by oat $(76.25 \mathrm{~mm})$, barley $(71 \mathrm{~mm})$ but in case of $P$. flabellatus mycelial growth of maize $(86.5 \mathrm{~mm})$ were followed by oat $(71.5 \mathrm{~mm})$, Barley $(67.25 \mathrm{~mm})$. Minimum mycelial growth was observed in wheat grain in P. florida $(54.5 \mathrm{~mm})$ and $P$. flabellatus $(50.75 \mathrm{~mm})$ but in case of $P$. sapidus, minimum mycelium growth was observed in pearl millet grain $(69 \mathrm{~mm})$ on $12^{\text {th }}$ day respectively. 
Table.1 Spawn growth $(\mathrm{mm})$ and growth rate $(\mathrm{mm} /$ day) of different Pleurotus spp.

\begin{tabular}{|c|c|c|c|c|c|c|c|c|c|c|c|c|}
\hline \multirow[t]{2}{*}{ Grains } & \multicolumn{4}{|c|}{ Pleurotus florida } & \multicolumn{4}{|c|}{ Pleurotus flabellatus } & \multicolumn{4}{|c|}{ Pleurotus sapidus } \\
\hline & $\begin{array}{l}4^{\text {th }} \\
\text { day }\end{array}$ & $\begin{array}{c}8^{\text {th }} \\
\text { day }\end{array}$ & $\begin{array}{l}12^{\text {th }} \\
\text { day }\end{array}$ & $\begin{array}{l}\text { Growth } \\
\text { rate }(\mathbf{m m} / \\
\text { day })\end{array}$ & $\begin{array}{l}4^{\text {th }} \\
\text { day }\end{array}$ & $\begin{array}{l}8^{\text {th }} \\
\text { day }\end{array}$ & $\begin{array}{l}12^{\text {th }} \\
\text { day }\end{array}$ & $\begin{array}{l}\text { Growth } \\
\text { rate } \\
\text { per day }\end{array}$ & $\begin{array}{l}4^{\text {th }} \\
\text { day }\end{array}$ & $\begin{array}{l}8^{\text {th }} \\
\text { day }\end{array}$ & $\begin{array}{l}12^{\text {th }} \\
\text { day }\end{array}$ & $\begin{array}{l}\text { Growth } \\
\text { rate } \\
\text { per day }\end{array}$ \\
\hline Sorghum & 21.00 & 42.00 & 66.00 & 5.50 & 18.50 & 40.50 & 64.5 & 5.38 & 29.25 & 50.00 & 89.00 & 7.42 \\
\hline Oat & 23.00 & 44.00 & 76.25 & 6.35 & 21.50 & 43.50 & 71.5 & 5.96 & 23.75 & 45.25 & 82.25 & 6.85 \\
\hline Barley & 20.75 & 45.50 & 71.00 & 5.92 & 19.50 & 41.50 & 67.25 & 5.60 & 24.25 & 46.25 & 76.00 & 6.33 \\
\hline Pearl Millet & 19.25 & 32.25 & 58.50 & 4.88 & 18.50 & 32.25 & 59.5 & 4.96 & 20.00 & 40.50 & 69.00 & 5.75 \\
\hline Maize & 34.75 & 62.00 & 89.25 & 7.44 & 32.50 & 60.75 & 86.5 & 7.21 & 36.50 & 60.75 & 90.00 & 7.50 \\
\hline Wheat grain & 17.50 & 32.00 & 54.50 & 4.54 & 16.25 & 31.50 & 50.75 & 4.23 & 25.00 & 44.75 & 77.00 & 6.42 \\
\hline CD at $5 \%$ & 3.02 & 2.557 & 2.27 & - & 2.168 & 2.27 & 1.98 & 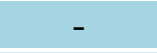 & 1.466 & 1.655 & 1.044 & - \\
\hline $\mathrm{SE}(\mathrm{m})$ & 1.009 & 0.854 & 0.759 & - & 0.724 & 0.759 & 0.661 & - & 0.489 & 0.553 & 0.349 & - \\
\hline
\end{tabular}

Fig.1 Different grain on spawn growth $(\mathrm{mm})$ and growth rate (mm/day) of three Pleurotus spp.

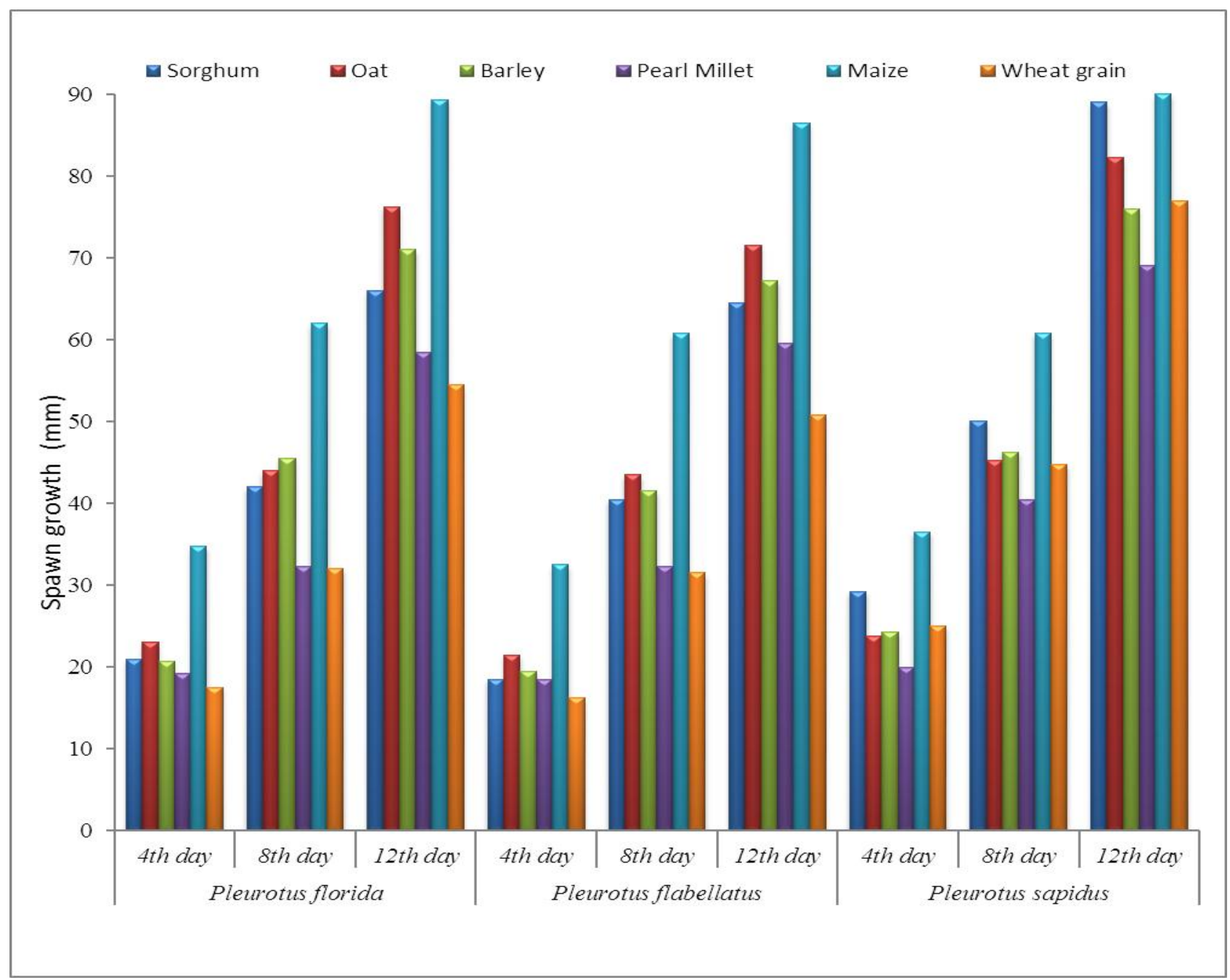


Similar observations were also reported by Pathmashini et al., (2008), revealed that the efficacy of four different types of grain spawns viz; kurakkan, maize (Zea mays), sorghum and paddy on oyster mushroom (Pleurotus ostreatus) production. Four types of spawns were tested on a medium based on sawdust. Highest mean numbers of sporophore (fruiting bodies) were noticed in the harvests obtained from sorghum spawn (7.67+ or -0.66). The kurakkan spawn significantly enhanced biological efficiency and increased size and yield, when compared with other spawn types viz; maize, sorghum, and paddy.

Mbogoh, et al., (2011) reported that the spawn is pure culture of mycelium growing on a solid substrate such as cereal grain. Maize, wheat and millet grains were used as substrates for production of grain mother spawns of Pleurotus ostreatus. Linear mycelium extension was measured.

Bhadana (2014) also reported that the best grain spawn with maximum spawn growth observed in the maize substrate which was the best, followed by wheat, then millet for the spawn growth.

Singh (2015) reported that, in case of $P$. djamor the maximum mycelial growth was found in chickpea while the minimum mycelial growth was recorded in barley grains, followed by wheat grain respectively.

Many workers worked on development of different grain spawns and their effect on yield. Pathmasini et al., 2008) used locally available grains of kurakkan (Eleusine coracana), maize (broken), sorghum (Sorghum bicolor) and paddy (Oryza sativa) for spawn production. According to him the kurakkan spawn produced an acceleration of spawn running, pin head formation, fruit body formation and increased yield compared with other types of spawn viz. maize, sorghum and paddy. Shah et al., (2004) took three types of grain for spawn production kurakkan (Eleusine coracana), maize (broken) (Zea mays), sorghum (Sorghum bicolor) and reported the spawn run appear earlier in kurukkan. Arulnandhy and Gayathri (2007) obtained a mean yield of $24 \mathrm{gm}$ on sawdust medium. Chaubey, (2010) used wheat, maize and sorghum grain spawn for the cultivation of oyster mushroom. Thulasi et al., (2010) reported spawn production of oyster mushroom on different substrates. Khan et al., (2011) reported different spawning methods of oyster mushrooms on cotton waste. It is concluded from the present study that all the three spp. On all six grains are suitable for spawn production but Maize grain is more efficient on for the spawn production of Pleurotus sapidus.

In case of spawn production maximum mycelial growth of strains $P$. florida, $P$. flabellatus and $P$. sapidus in maize and sorghum grain was obtained on $12^{\text {th }}$ days in bottles. In case of $P$. sapidus maximum mycelium growth was observed in maize grain $(90 \mathrm{~mm})$ while minimum mycelium growth was found in Wheat grain substrate $(77 \mathrm{~mm})$, In case of $P$. florida maximum mycelium growth was observed in maize grain $(89.25 \mathrm{~mm})$ while minimum mycelium growth was found in wheat grain substrate $(54.5 \mathrm{~mm})$ and in case of $P$. flabellatus maximum mycelium growth was observed in maize grain $(86.50 \mathrm{~mm})$ while minimum mycelium growth was found in Wheat grain substrate $(50.75 \mathrm{~mm})$.

\section{References}

Arulnandhy V. and Gayathri T. (2007) Identification of suitable and efficient substrate for the production of oyster (Pleurotus ostreatus) mushrooms. Undergraduate research report, Department of Agricultural Biology, Eastern University, 
Sri Lanka.

Bano Z. and Srivastava H.C. (1962) Studies on cultivation of Pleurotus spp. on paddy straw: Food Science, 11: 363-365.

Bhadana N. K. (2014) Studies on production technology and major disease management of oyster mushroom. Ph.D thesis, SVPUA\&T, Meerut. 30-35.

Chang S-T (2006) The World Mushroom Industry: Trends and technological development. Int J Med Mushrooms: 297314.

Chang S-T, Miles PG (2004) Mushrooms: cultivation, nutritional value, medicinal effect, and environmental impact. Boca Raton, London, New York, Washington DC: CRC Press LLC. 477 p.

Chaubey A. (2010) Studies on cultivation technology of medicinal mushrooms with special reference to marketing potential in Bundelkhand region. Ph. D. Thesis. Dr. H.S. Gour, University, Sagar, M.P.

Jain A. K. (2005) Thesis on Mushroom Cultivation with special reference to Pleurotus florida and their Marketing potential in Sagar Region. 14. Khan, M.W. Ali, M, A, and Farooq, M. (2011). Growth respons of oyster mushroos (Pleurotus ostreatus) by using different methods of spawning raised on cotton waste. Pak. J. Phytopathol., 23 (2): 156-158.

Khan M.W., Ali M. A. and Farooq M. (2011) Growth respons of oyster mushroos (Pleurotus ostreatus) by using different methods of spawning raised on cotton waste. Pak. J. Phytopathol., 23 (2): 156158.

Mbogoh J.M., Anjichi V.E., Rotich F. and Ahoya N.K. (2011) Substrate effects of grain spawn production on mycelium growth of oyster mushroom. Acta Horticulturae. (911): 469-471. 13.

Pathmashini, L., Arulnandhy, V. and Wilson, R.S. (2008). Cultivation of oyster mushroom (Pleurotus ostreatus) on saw dust. Cey. J. Sci. (Bio. Sci.) 37 (2): 177-182.

Quimio T. H. (1978) Introducing Pleurotus flabellatus for your dinner table Mushroom Journal, 69: 282-283.

Royse D.J. and Schisler L.C. (1980) Mushrooms, their consumption, production and culture development. Intr. Discipl. Sci. Rev., 5(4): 324-332.

Shah Z. A., Asar M. and Ishtiaq. (2004) Comparative study on cultivation and yield performance of oyster mushroom on different substrates (wheat straw, leaves, saw dust). Pakistan J. Nutrition 3: 159-160.

Singh S. (2015) Studies on spawn production technology of oyster mushroom (Pleurotus djamor). M.Sc. Thesis, SVPUA\&T, Meerut, 40-48.

Thulasi E. P., Thomas D., Ravichandran B. and Madhusudhanan K. (2010) Mycelial culture and spawn production of two oyster Mushrooms, Pleurotus florida and Pleurotus eous on Different Substrates. International Journal of Biological Technology. 1(3): 39-42.

Verma R.N. (1998) Recent Advances in Mushroom Research in India In: Advances in Mushroom Biology and Production (Rai, R.D., Dhar, B.L. and Verma, R.N. eds). Mushroom Society of India NCRM, Chambagahat, Solan. pp. 1-30.

Zadrazil F. (1980) Conservation of different plant waste in to feed by basidiomycetes. Europ. J. Appl. Microbial. Biotechnol, 2: 243-248.

\section{How to cite this article:}

Ajay Kumar Mishra, Gopal Singh, Abhishek Kumar, Amit Kumar Yadav and Mohit. 2018. Comparative Studies of Span Growth on Different Grains Substrate in Three Pleurotus spp. (Pleurotus florida, Pleurotus flabellatus and Pleurotus sapidus). Int.J.Curr.Microbiol.App.Sci. 7(06): 3239-3245. doi: https://doi.org/10.20546/ijcmas.2018.706.381 